\title{
Pepper mild mottle virus infection in cayenne and sweet pepper in Indonesia
}

\author{
Tri Asmira Damayanti $^{1}{ }^{10} \cdot$ Fitrianingrum Kurniawati $^{1}$
}

Received: 10 November 2021 / Accepted: 2 February 2022 / Published online: 7 February 2022

(c) The Author(s) under exclusive licence to Australasian Plant Pathology Society Inc. 2022

\begin{abstract}
This is a report of the natural occurrence of Capsicum frutescens (cayenne pepper) and Capsicum annuum L. (sweet pepper) infection with pepper mild mottle virus (PMMoV) in Indonesia, which was detected serologically via dot-immunobinding assay and confirmed by RT-PCR of the coat-protein-encoding gene and DNA sequencing. Phylogenetically, the cayenne and sweet-pepper isolates were closely related to Capsicum spp. isolates from Turkey, Italy and Korea, with 99.1\%-99.5\% and $100 \%$ identity at the nucleotide and amino acid levels, respectively.
\end{abstract}

Keywords Capsicum spp. · One-step RT-PCR · Sequencing · Tobamovirus

Sweet pepper (Capsicum annuum L.) and cayenne pepper (C. frutescens L.) are essential cash crops with a high economic value in Asian countries, including Indonesia. Both crops are utilized widely in Asian cuisine. However, viral infection in Capsicum spp. has become a critical constraint regarding the production of these crops, regardless of where they are grown. Cucumber mosaic virus (CMV) (Sutrawati et al. 2016), chilli veinal mottle virus (ChiVMV) (Hidayat et al. 2012) and begomoviruses associated with pepper yellow leaf curl virus (PYLCV) are important viruses that infect chilli peppers in Indonesia (Hidayat et al. 2006; Tsai et al. 2006; Kesumawati et al. 2019). Among them, PYLCV infection is devastating in this country.

Pepper mild mottle virus (PMMoV) belongs to the genus Tobamovirus in the Virgaviridae family. Its genome consists of a single-stranded positive-sense RNA of 6357 nucleotides (Garcia-Luque et al. 1990; Kirita et al. 1997). PMMoV is easily transmitted by mechanical transmission, seeds and soil (Komuro and Iwaki 1969; Lanter et al. 1982). Based on the reaction upon inoculation in specific plant genotypes carrying the resistance genes to tobamoviruses $\mathrm{L}^{+}, \mathrm{L}^{1}, \mathrm{~L}^{2}$ and $\mathrm{L}^{3}$, PMMoV is classified as pathotype $\mathrm{P}_{0}, \mathrm{P}_{1}, \mathrm{P}_{1,2}$ and $\mathrm{P}_{1,2,3}$ (Boukema et al. 1980) and $P_{1,2,3,4}$ (Antignus et al. 2008). To date, PMMoV has remained a quarantine pest in Indonesia.

Tri Asmira Damayanti

triadys@apps.ipb.ac.id

1 Department of Plant Protection, Faculty of Agriculture, IPB University, Bogor 16680, Indonesia
Recently (March/April 2021), surveys were conducted to identify tobamoviruses that infect sweet and cayenne peppers. Leaf samples were collected purposively targeting PMMoV-like symptom such as yellow or chlorosis mottling, chlorosis, leaf malformation and puckering from several pepper-cultivation areas in the Lembang sub-district, West Java, and the Pujon sub-district, East Java, Indonesia. A total of 55 symptomatic leaf samples including 50 samples of sweet pepper and five samples of cayenne pepper var. Prentul were collected. The leaf samples were wrapped in tissue paper and dried in silica gel, followed by storage in a refrigerator at $4{ }^{\circ} \mathrm{C}$.

The viruses were detected serologically by dotimmunobinding assay (DIBA) using specific PMMoV antisera (DSMZ, Germany). The DIBA test includes a series of steps, such as leaf-juice blotting onto a nitrocellulose membrane, blocking, antisera reaction and addition of the NBT/BCIP substrate; subsequently, in the presence of the enzyme, a precipitate is produced and deposited in the dot (Mahmood et al. 1997). Subsequently, the samples that were serologically positive for PMMoV were confirmed by RT-PCR and DNA sequencing.

Total nucleic acids were extracted from leaf samples using a commercial plant RNA purification kit (GeneJET, Thermo Scientific). The virus-specific cDNA was amplified using a one-step RT-PCR mixture in a total reaction volume of $50 \mu \mathrm{L}$ consisting of $12.5 \mu \mathrm{L}$ of MyTaq ${ }^{\mathrm{TM}}$ HS Red Mix (Bioline Meridian Bioscience, Memphis, TN, USA), $5 \mu \mathrm{L}$ of $0.1 \mathrm{M}$ DTT, $5.0 \mu \mathrm{L}$ each of $10 \mu \mathrm{M}$ forward and reverse 
primers, $20 \mathrm{U}(200 \mathrm{U} / \mu \mathrm{L})$ of RevertAid reverse transcriptase MMuLV (Thermo Scientific, Waltham, MA, USA), $0.2 \mu \mathrm{L}$ (40 U/ $\mu \mathrm{L}$ ) of RiboLock RNAse Inhibitor (Thermo Scientific) and $4 \mu \mathrm{L}(15 \mathrm{ng} / \mu \mathrm{L})$ of total RNA (the mix was adjusted to the total volume of $50 \mu \mathrm{L}$ using nuclease-free water). RTPCR detection was performed using the specific primer pair consisting of PMMoVdF (5'-GTAAGAGAAATGATAATA AGGGTTTG-3') and PMMoVdR (5'-CGTTCGCAAATA CACGTCAC $-3^{\prime}$ ) for the coat protein $(C P)$ gene (Zhou et al. 2021). The expected amplicon size was 720 bp. RT-PCR products were directly applied to Sanger sequencing at Apical Scientific Sequencing Services in Malaysia. The nucleotide sequences were analysed using BLASTN (https://blast. ncbi.nlm.nih.gov/Blast.cgi) to identify local regional similarities between the sequences. Subsequently, the sequences were aligned to corresponding isolates in GenBank using the ClustalW program (Thompson et al. 1994) in the BioEdit v7.05 software (http://www.mbio.ncsu.edu/BioEdit/bioedit. html), to obtain a sequence identity matrix. A phylogenetic tree based on amino acid sequences was constructed using the MEGA X software with the neighbour-joining algorithm based on the p-distance model and a bootstrap support value of 1.000 replicates (Kumar et al. 2018).

Fourteen samples of sweet peppers and one sample of cayenne pepper showed a positive reaction, as assessed based on a strong purple colour on the DIBA test. One-step RT-PCR detection of cayenne and the pooled sweet peppers confirmed the DIBA test results; an amplicon with an expected size of approximately $720 \mathrm{bp}$ was amplified using PMMoV-specific primer pairs (Supplementary Fig. 1). The full-length coat-protein sequences sized 474 bp encoding 157 aa were identical among the two isolates and exhibited an identity of $93.2 \%-99.5 \%$ and $96.8 \%-100 \%$ with the corresponding $\mathrm{PMMoV}$ isolates from different origins available in the GenBank database, at the nucleotide and amino acid levels, respectively (Supplementary Table 1). The isolates were deposited in the GenBank database under accession numbers LC655143 and LC655144.

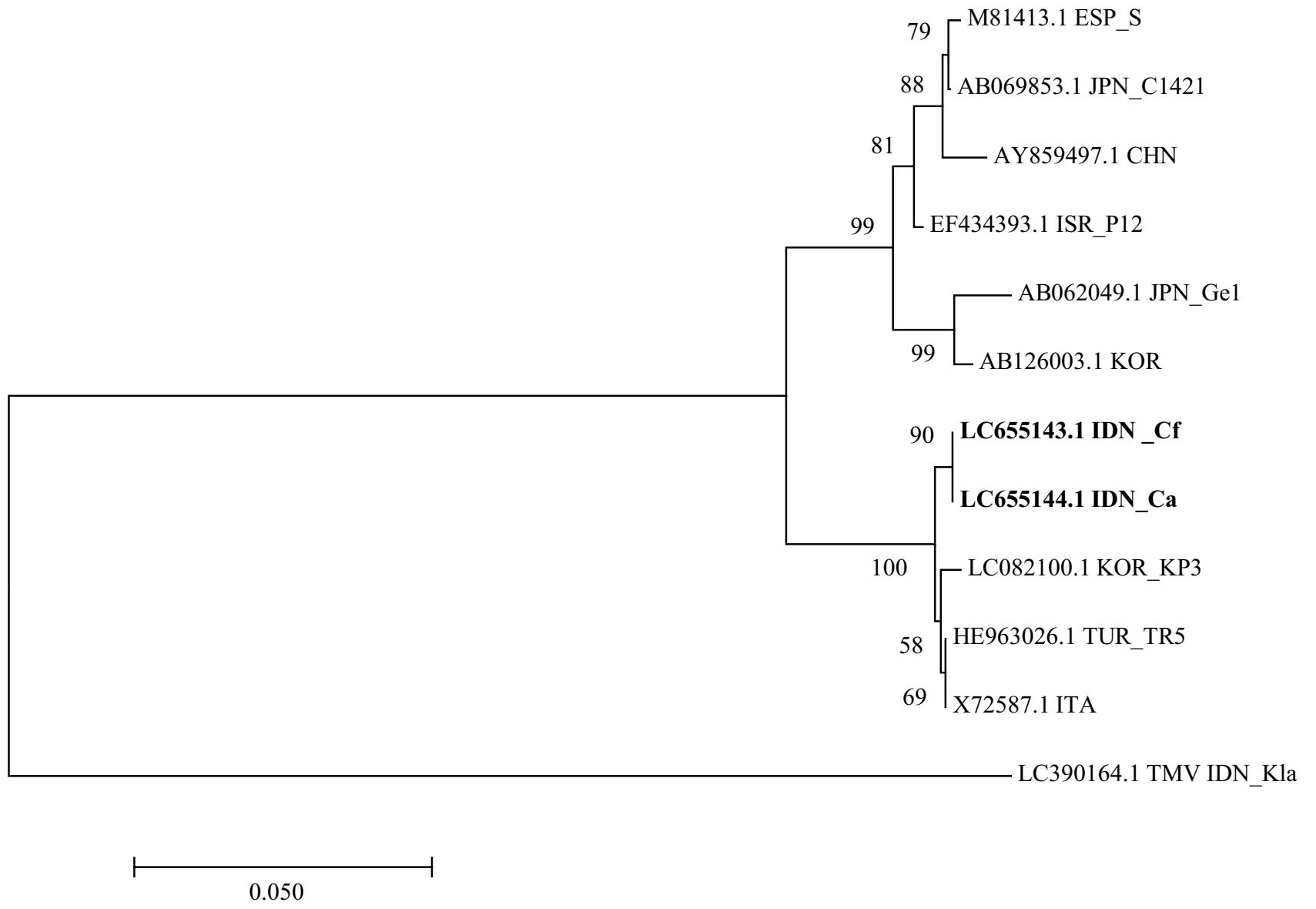

Fig. 1 Phylogenetic tree of Indonesian isolates (bold font) of pepper mild mottle virus (PMMoV) showing an evolutionary relationship with corresponding isolates from other countries, as assessed based on the full-length amino acid sequences of the coat protein gene. The tree was constructed using the neighbour-joining method implemented in MEGA X. The numbers located at the branch node indicate the confidence values (\%) from bootstrap analysis using 1000 replicates; values $>50 \%$ were included exclusively. Out-group: tobacco mosaic virus (TMV) 
A phylogenetic analysis of the full-length nucleotide sequences of the $C P$ gene revealed that both the $C$. frutescens $(\mathrm{Cf})$ and $C$. annuum $(\mathrm{Ca})$ isolates clustered in the same clade together with Korean (KP3), Turkish (TR5) and Italian isolates, and differed from clusters of Korean, Japanese, Israeli and Spanish isolates (Fig. 1). Moreover, the phylogenetic analysis supported the grouping of the Indonesian isolates PMMoV-Cf and-Ca within the pathotype $\mathrm{P}_{1,2,3}$ cluster. Three amino acids located at positions 6,139 and 148 were reported as uniquely common molecular prints of pathotype $\mathrm{P}_{1,2,3}$. Among them, the substitution of methionine (M) with asparagine $(\mathrm{N})$ at position 139 had been reported as being key for $\mathrm{L}^{3}$-resistance-overcoming isolates (Caglar et al. 2013). The Cf (LC655143) and Ca (LC655144) isolates also had similar amino acids at those positions. Previously, the $\mathrm{P}_{1,2,3}$ isolates were reported in Italy (PMMoV-I), Japan (PMMoV-J), Israel (PMMoV-Is) and Turkey (PMMoV-TR5, TRf1, TRf2) (Garcia-Luque et al. 1993; Tsuda et al. 1998; Antignus et al. 2008; Caglar et al. 2013). However, it is necessary to perform phenotyping on differential hosts to ensure the pathotype of these isolates. This report might extend the recorded number of countries with PMMoV pathotype $\mathrm{P}_{1,2,3}$ reports, although it is assumed that it is spread more widely.

The presence of PMMoV represents a new threat against Capsicum spp. production in Indonesia. These data will be useful for the surveillance and routine monitoring of the virus, rigorous seed quality control and breeding programs in the future, to overcome PMMoV infection and spread in Indonesia. To the best of our knowledge, this is the first report of PMMoV infection in peppers in Indonesia.

Supplementary information The online version contains supplementary material available at https://doi.org/10.1007/s13314-022-00451-5.

Acknowledgements This study was supported by a research grant from the Ministry of Education, Culture, Research and Technology, the Republic of Indonesia (1/E1/KP.PTNBH/2021).

\section{Compliance with ethical standards}

Conflict of interest The authors declare that they have no conflict of interest.

Human and animal rights This article does not contain any studies with human participants or animals performed by any of the authors.

\section{References}

Antignus Y, Lachman O, Pearlsman ML, Rosner A (2008) A new pathotype of pepper mild mottle virus (PMMoV) overcomes the L4 resistance genotype of pepper cultivars. Plant Dis 92:10331037. https://doi.org/10.1094/PDIS-92-7-1033

Boukema IW, Jaj-Jsen K, Hofman K (1980) Strains of TMV and genes for resistance in Capsicum. Proc. 4th Capsicum eucarpia Meeting. Wageningen, 44-48
Caglar BK, Fidan H, Elbeaino T (2013) Detection and molecular characterization of pepper mild mottle virus from Turkey. J Phytopathol 161:434-438. https://doi.org/10.1111/jph.12068

Garcia-Luque I, Serra MT, Alonso E, Wicke B, Ferrero ML, DiazRuiz JR (1990) Characterization of a Spanish strain of pepper mild mottle virus (PMMV-S) and its relationship to other tobamoviruses. J Phytopathology 129:1-8. https://doi.org/10.1111/j. 1439-0434.1990.tb04284.x

Garcia-Luque I, Ferrero ML, Rodriguez JM, Alonso E, de la Cruz A, Sanz AI, Vequero C, Serra MT, Diaz-Ruiz JR (1993) The nucleotide sequence of the coat protein genes and $3^{\prime}$ noncoding regions of two resistance-breaking tobamoviruses in pepper shows that they are different viruses. Arch Virol 131:75-88. https://doi.org/ 10.1007/BF01379081

Hidayat SH, Chatchawankanpanich O, Rusli E, Aidawati N (2006) Begomovirus associated with pepper yellow leaf curl disease in West Java Indonesia. J Mikrobiol Indones 11:87-90

Hidayat SH, Opriana E, Manzila I, Sujiprihati S (2012) Occurrence of chili veinal mottle virus (ChiVMV) in Indonesia and response of chili germplasms to ChiVMV infection. J ISSAAS 18(2):55-61

Kesumawati E, Okabe S, Homma K, Fujiwara I, Zakaria S, Kanzaki S, Koeda S (2019) Pepper yellow leaf curl Aceh virus: a novel bipartite begomovirus isolated from chili pepper, tomato, and tobacco plants in Indonesia. Arch Virol 164:2379-2383. https://doi.org/10.1007/ s00705-019-04316-8

Kirita M, Akutsu K, Watanabe Y, Tsuda S (1997) Nucleotide sequence of the Japanese isolate of pepper mild mottle tobamovirus. Ann Phytopathol Soc Jpn 63:373-376. https://doi.org/10.3186/jjphytopath. 63.373

Komuro Y, Iwaki M (1969) Presence of tobacco mosaic virus in roots of field-grown tomato plants healthy in appearance. Ann Phytopathol Soc Jpn 35:294-298

Kumar S, Stecher G, Li M, Knyaz C, Tamura K (2018) MEGA X: Molecular Evolutionary Genetics Analysis across computing platforms. Mol Biol Evol 35(6):1547-1549. https://doi.org/10.1093/molbev/ msy096

Lanter JM, McGuire JM, Goode MJ (1982) Persistence of tomato mosaic virus in tomato debris and soil under field conditions. Plant Dis 66:552-555. https://doi.org/10.1094/PD-66-552

Mahmood T, Hein GL, French RC (1997) Development of serological procedures for rapid and reliable detection of wheat streak mosaic virus in a single wheat curl mite. Plant Dis 81(3):250-253. https:// doi.org/10.1094/PDIS.1997.81.3.250

Sutrawati M, Djamilah, Kinata A (2016) Infection of cucumber mosaic virus and Chilli veinal mottle virus on Chilli pepper in Rejang Lebong Regency, Bengkulu. J Fitopatol Indones 8(4):110-115. https:// doi.org/10.14692/jif.8.4.110

Thompson JD, Higgins DG, Gibson TJ (1994) CLUSTAL W: improving the sensitivity of progressive multiple sequence alignment through sequence weighting, position-specific gap penalties and weight matrix choice. Nucleic Acids Res 22:4673-4680. https://doi.org/ 10.1093/nar/22.22.4673

Tsai WS, Shih SL, Green SK, Rauf A, Hidayat SH, Jan FJ (2006) Molecular characterization of pepper yellow leaf curl Indonesia virus in leaf curl and yellowing diseased tomato and pepper in Indonesia. Plant Dis 90:247. https://doi.org/10.1094/PD-90-0247B

Tsuda S, Kirita M, Watanabe Y (1998) Characterization of pepper mild mottle tobamovirus strain capable of over-coming the L3 genemediated resistance, distinct from the resistance-breaking Italian isolate. Mol Plant Microbe Interact 11:327-331. https://doi.org/10. 1094/MPMI.1998.11.4.327

Zhou WP, Li YY, Li F, Tan GL (2021) First report of natural infection of tomato by Pepper mild mottle virus in China. J Plant Pathol 103:363. https://doi.org/10.1007/s42161-020-00688-y 